HUMANIKA Vol. 23 No. 2 (2016) ISSN 1412-9418

Seni Pertunjukan Tradisional Di Persimpangan Zaman: Studi Kasus Kesenian Menak Koncer

Sumowono Semarang

Laura Andri R.M., S.S.,M.A.

\title{
SENI PERTUNJUKAN TRADISIONAL DI PERSIMPANGAN ZAMAN: STUDI KASUS KESENIAN MENAK KONCER SUMOWONO SEMARANG
}

\author{
Oleh : \\ Laura Andri R.M. \\ Fakultas Ilmu Budaya Universitas Diponegoro \\ lauraandrirm@yahoo.co.id
}

\begin{abstract}
In Indonesia, each province has its own traditional culture. Traditional arts are used to express the beauty of the human soul. In traditional artwork implicit message of the society of knowledge, ideas, beliefs and values norms. In addition to the function of rituals, traditional performing arts is also being used to honor and commemorate the influential figures in the local community, heroism, patriotism and nationalism. One example of a traditional art that has the functionality is Menak Koncer. Menak Koncer is a community-owned art Sumowono, Kabupaten Semarang, Jawa Tengah raised to preserve the culture and values in society. Through a qualitative descriptive approach with observation techniques and literature, it was found that at the next stage of development, especially in the modern society, arts performances Menak Koncer shift function just as mere entertainment. Menak Koncer existence as art and traditional culture in Indonesia progressively eroded by the expansion of global art and culture. Therefore, efforts must be made to preserve the arts and culture in the midst of changing times and foreign cultural influences have been increasing in Indonesia.
\end{abstract}

Keywords : traditional art , modernization , a cultural shift , cultural preservation

\section{PENDAHULUAN}

Kebudayaan dipahami sebagai suatu hal yang mencakup pengetahuan, kepercayaan, kesenian, moral, adat istiadat, kebiasaan serta kemampuan yang didapatkan manusia dalam perannya sebagai anggota masyarakat. Dalam kehidupan sehari-hari, masyarakat mengartikan kebudayaan sebagai peninggalan sejarah yang bersifat tradisional seperti tarian daerah, alat musik daerah, senjata tradisional, bahasa daerah, dan lain sebagainya. Di Indonesia, hampir setiap propinsi memiliki kebudayaan tradisionalnya sendiri. Oleh sebab itu Indonesia dijuluki sebagai negara yang kaya akan budaya.

Kesenian tradisional adalah salah satu jenis budaya tradisional. Kesenian tradisional merupakan sarana yang digunakan untuk mengekspresikan rasa keindahan dari dalam jiwa manusia. Suatu hasil ekspresi hasrat manusia akan keindahan dengan latar belakang tradisi atau sistem budaya masyarakat pemilik kesenian. Dalam karya seni tradisional tersirat pesan dari masyarakatnya berupa pengetahuan, gagasan, kepercayaan dan nilai norma.

Penciptaan kesenian tradisional selalu berdasarkan pada filosofi sebuah aktivitas dalam suatu budaya, bisa berupa aktivitas religius maupun seremonial/istanasentris. Ia muncul sebagai bagian dari gagasan atau ide sekelompok masyarakat yang dikemas secara artististik dan mengandung nilai-nilai yang berkembang dalam masyarakat tersebut. Kesenian tradisional yang ada di Indonesia 


\section{HUMANIKA Vol. 23 No. 2 (2016) ISSN 1412-9418}

Seni Pertunjukan Tradisional Di Persimpangan Zaman: Studi Kasus Kesenian Menak Koncer

Sumowono Semarang

Laura Andri R.M., S.S.,M.A.

sangat banyak jumlahnya. Penelitian yang berkaitan dengan seni pertunjukan yang dilakukan Brandon, menyebutkan bahwa jumlah seni pertunjukan yang ada di Asia Tenggara, $75 \%$ berada di Indonesia, sedangkan yang $25 \%$ ada di negara-negara Asia Tenggara yang lain, seperti Malaysia, Singapura, Brunai Darussalam, Myanmar, Thailand, Laos, dan Vietnam. Potensi budaya bangsa yang banyak jumlahnya ini amat penting untuk meningkatkan harkat, kehormatan, dan pemahaman tentang arti kemanusiaan (Bandem, 2001: 6).

Sebelum masa kemerdekaan, masyarakat terutama daerah pedesaan memfungsikan kesenian tradisional sebagai kegiatan ritual. Demi untuk mempertahankan dan meningkatkan taraf hidup, mereka merasa perlu memenuhi berbagai kebutuhan yang berlaku secara universal. Kesenian merupakan kebutuhan integritas untuk meningkatkan dan melangsungkan taraf hidup. Masyarakat petani pedesaan (peasant society) Jawa yang tergolong dalam peringkat hidup subsistens misalnya, telah lama mengembangkan kesenian sebagai suatu kebutuhan integrif dan secara fungsional berkaitan dengan kebudayaan yang berlaku pada masyarakat tersebut. Kata "Jawa" yang dimaksud pada uraian ini tidak mengacu pada pengertian geografis, melainkan mengacu pada pengertian etnografis. Maka, yang dimaksud "petani Jawa" adalah petani yang beretnis Jawa. Mereka memandang kesenian sebagai salah satu wahana untuk melegitimasi keberadaan dan mempertahankan identitasnya (Koentjaraningrat, 1994:211220).

Masyarakat petani pedesaan Jawa percaya bahwa manusia bisa mempengaruhi tanaman agar menjadi subur dengan menyelenggarakan upacara yang melambangkan kesuburan.Selain itu, kesenian tradisional biasanya dilakukan musiman, misalnya pada masa tanam atau panen padi. Hal ini berkaitan dengan fungsinya sebagai kegiatan ritual. Para petani mengadakan upacara-upacara yang ditujukan pada Tuhan Sang Pemilik Alam sebagai bentuk ucapan syukur serta meminta keberkahan agar panen dapat berhasil. Sebagai bagian dari proses ritual, maka aturan, makna serta kekuatan yang terkandung pada penampilan kesenian tradisional itu lebih diutamakan. Dengan demikian, dalam menyelenggarakan prosesi, berbagai persyaratan sesuai kaidah-kaidah ritual yang telah mentradisi tidak boleh ditinggalkan, baik oleh pemeran ataupun penyelenggara. Kaidahkaidah ritual yang telah mentradisi tersebut dapat berupa pemilihan waktu dan tempat yang tepat untuk menyelenggarakan pertunjukan, pelaku atau pemeran harus orang yang terpilih, serta kelengkapan berbagai sesaji.

Selain fungsi ritual, kesenian tradisional digunakan sebagai media pendidikan dan penggambaran identitas bangsa. Seni pertunjukan tradisional ini lebih difungsikan untuk memperingati peristiwa tertentu, menghormati serta mengenang tokoh-tokoh yang berpengaruh dalam masyarakat setempat, heroisme, patriotisme dan nasionalime. Salah satu contoh kesenian tradisional yang memiliki fungsi tersebut adalah Menak Koncer. Menak Koncer merupakan kesenian yang dimiliki masyarakat Sumowono Kabupaten Semarang Jawa Tengah yang dimunculkan untuk melestarikan budaya dan nilai-nilai dalam masyarakatnya. Sayangnya, saat ini animo serta minat masyarakat modern terhadap seni pertunjukan tradisional ini semakin menipis.

Modernisasi menggeser fungsifungsi awal dari kesenian tradisional. Masuknya budaya asing ke Indonesia berbenturan dengan budaya tradisional yang bersifat lokal sehingga fungsi kesenian tradisional mengalami pergeseran. Proses sekularisasi dan komersialisasi yang menghebat pada abad XX memberikan dampak negatif bagi 
HUMANIKA Vol. 23 No. 2 (2016) ISSN 1412-9418

Seni Pertunjukan Tradisional Di Persimpangan Zaman: Studi Kasus Kesenian Menak Koncer

Sumowono Semarang

Laura Andri R.M., S.S.,M.A.

kesenian tradisional. Fungsi ritual, pendidikan serta penggambaran identitas bangsa bergeser menjadi kegiatan komersial. Walaupun fungsi awal itu sendiri masih melekat namun kadarnya menyusut tergantung kebutuhan masyarakat setempat.

Kesenian modern yang muncul belakangan menyebabkan kesenian tradisional semakin tergerus oleh budaya zaman. Kesenian tradisional makin sulit ditemukan di kota-kota. Kondisi krisis penonton serta penurunan frekuensi pementasan mengakibatkan banyak kelompok seni yang mengalami mati suri atau bahkan berhenti sama sekali. Faktor penting yang berperan besar dalam krisis tersebut adalah pengaruh teknologi informasi. Meningkatnya sarana dan prasarana informasi terutama teknologi elektronika, seperti radio dan televisi selain memberi pengaruh positif, ternyata juga membawa pengaruh negatif. Salah satu pengaruh negatif dari radio dan televisi adalah semakin menurunnya minat masyarakat menonton secara langsung seni pertunjukan kesenian tradisional. Semakin meluasnya kawasan industri serta pemukiman, maka semakin sempit pula area persawahan yang ada. Para petani mulai beralih profesi mencari pekerjaan lain. Masalah itu juga menjadi penyebab keberadaan kesenian tradisional yang semakin menghawatirkan. Jika animo serta minat masyarakat modern terhadap seni pertunjukan tradisional semakin menipis, maka akan semakin banyak seni tradisi yang mati atau punah.

\section{SEKILAS TENTANG MENAK} KONCER

$\begin{array}{lcr}\text { Kesenian } & \text { tradisional } & \text { Menak } \\ \text { Koncerberkembang } & \text { di } & \begin{array}{l}\text { Dusun } \\ \text { Pledokan, }\end{array} \\ \text { Resowinangun, Desa } & \text { Kabupaten } \\ \text { Kecamatan Sumowono, } & \text { Kabuparatistiwa } \\ \text { Semarang Jawa Tengah. Tarian Rakyat } & \text { Remak Koncer lahir dari suatu peristiwa }\end{array}$

sejarah, dilatarbelakangi oleh perang besar yang terjadi di tanah Jawa. Konon, tari rakyat ini diciptakan oleh sisa pengikut Pangeran Diponegoro yang selamat dan melarikan diri ke arah utara.

Dahulu, tarian ini berasal dari Temanggung, namun dalam perkembangannya justru hidup di daerah Sumowono. Seni tradisional Menak Koncer adalah seni tradisi yang diciptakan untuk menghormati tokoh pahlawan Pangeran Diponegoro. Setelah Pangeran Diponegoro ditangkap oleh Belanda, para prajurit yang setia mengawal dan mendampingi dalam peperangan kembali ke tempat tinggal masing-masing. Namun kecintaan pada sang tokoh serta rasa patriotisme dan nasionalisme yang besar, mereka lestarikan dalam bentuk tarian Menak Koncer. Hal ini bertujuan agar masyarakat luas dan keturunan mereka tetap memiliki rasa patriotisme dan nasionalime tinggi serta penghormatan yang besar terhadap Pangeran Diponegoro. Menak Koncer difungsikan sebagai kegiatan ritual dalam peristiwa-peristiwa tertentu. Saat menyaksikan tarian rakyat ini, penonton seakan dibawa ke abad 19. Bagaimana dua kekuatan yang saling berhadapan masing-masing menunjukkan kebolehannya. Para penari diiringi berbagai macam alat perkusi seperti genderang, timpring (rebana kecil) dan bende.

Dalam pementasannya, kesenian ini dimainkan oleh banyak orang. Biasanya berjumlah 14 personil yang terbagi menjadi dua kelompok yang berbaris berdampingan. Ada seseorang yang berperan sebagai komandan, tugasnya mengarahkan posisi gerak yang harus dijalankan oleh para penari. Tiap baris terdiri dari tujuh orang. Baris pertama mewakili pasukan Diponegoro, sedangkan baris lainnya mewakili serdadu Belanda. Formasi baris berjumlah tujuh orang dimaksudkan untuk menggambarkan tujuh pemimpin yang memimpin gladi perang 
kala itu, dengan berbagai jenis senjata yang dibawanya.

Gerak tari dibagi menjadi tiga babak. Babak pertama merupakan gladi (latihan) pasukan Diponegoro, babak kedua adalah gladi pasukan Belanda, sedangkan babak ketiga merupakan pertempuran antara kedua belak pihak. Kedua kelompok dibedakan berdasarkan kostum dan atribut yang dikenakan. Pasukan Belanda mengenakan seragam Koninklijk Leger lengkap dengan sepatu boot dan pangkat titulernya. Mereka dilengkapi pedang. Sedangkan pasukan Diponegoro memakai busana surjan dengan dilengkapi tombak, pedang serta perisai.

Seni Pertunjukan tradisional Menak Koncer juga mengalami pasang surut dan mati suri. Melemahnya animo masyarakat setempat terhadap kesenian tradisional ini mengakibatkan kegiatannya sempat vakum lama. Mulai tahun 1960 mati suri, barulah pada tahun 2006 kesenian ini mulai diaktifkan kembali. Organisasi kesenian ini diberi nama Karya Budaya. Mereka mulai mengisi acara-acara di tingkat desa maupun kabupaten. Sekarang, kelompok seni "Karya Budaya" dipimpin oleh Purwanto dengan Waljiono sebagai wakilnya.

Berkaitan dengan masalah vakum atau mati suri, masalah regenerasi menjadi bagian tak terpisahkan dari usaha pengembangan seni pertunjukan Menak Koncer. Tanpa memperhatikan aspek regenerasi ini, usaha pelestarian, revitalisasi, dan pengembangan kesenian Menak Koncer akan menghadapi kesulitan. Menurut Siti Munawaroh (2007), pada dasarnya produk seni pertunjukan tradisional dapat "dijual" baik kepada para peminat yang terdiri dari atas masyarakat kita sendiri maupun kepada orang asing sebagai wisatawan. Oleh karena itu, pertunjukan merupakan kegiatan kreatif berkaitan dengan usaha yang menyangkut pengembangan konten, produksi pertunjukan, tarian tradisional, tarian kontemporer, drama, musik tradisional, desain dan pembuatan busana pertunjukan, tata panggung, dan tata pencahayaan.

\section{MENAK KONCERDALAM PERGESERAN BUDAYA}

Modernisasi berdampak pada semua aspek kehidupan, salah satunya adalah adanya pergeseran budaya. Perubahan budaya terjadi di dalam masyarakat tradisional, yakni perubahan dari masyarakat tertutup menjadi masyarakat yang lebih terbuka, dari nilai-nilai yang bersifat homogen menjadi pluralisme. Ilmu pengetahuan dan teknologi telah mengubah dunia secara mendasar. Komunikasi dan sarana transportasi internasional telah menghilangkan batas-batas budaya setiap bangsa.

Permasalahan pergeseran budaya akibat modernisasi juga berdampak pada perkembangan kesenian tradisonal Menak Koncer. Perubahan pola hidup masyarakat yang lebih modern menjadikan mereka lebih memilih kebudayaan baru yang mungkin dinilai lebih menarik dan praktis dibandingkan dengan budaya lokal. Perkembangan teknologi informasi yang semakin canggih menawarkan banyak alternatif hiburan yang lebih beragam yang kemungkinan lebih menarik jika dibanding dengan kesenian tradisional Menak Koncer. Kondisi ini menyebabkan makin tersisihnya kesenian tersebut dari kehidupan masyarakat pemiliknya. Dengan datangnya perubahan sosial yang hadir sebagai akibat proses industrialisasi dan sistem ekonomi pasar serta globalisasi informasi maka kesenian tradisional ini pun mulai bergeser ke arah kesenian yang berdimensi komersial. Menak Koncer tidak lagi digunakan sebagai alat ritual, pendidikan, patriotisme, heorisme serta nasionalisme. Kesenian yang awalnya sakral kini menjadi lebih banyak bersifat hiburan. Menak Koncer mulai tersingkir 
HUMANIKA Vol. 23 No. 2 (2016) ISSN 1412-9418

Seni Pertunjukan Tradisional Di Persimpangan Zaman: Studi Kasus Kesenian Menak Koncer

Sumowono Semarang

Laura Andri R.M., S.S.,M.A.

dan kehilangan fungsinya. Hal ini sangat disayangkan mengingat Menak Koncer merupakan kesenian tradisional yang sarat akan pesan moral.

KesenianMenak Koncer mengalami krisis eksistensi. Sepinya penikmat serta manajemen yang tidak tertata rapi sempat membuat kesenian ini menjadi mati suri. Terjadinya mobilitas lapangan kerja dari petani dan penari Menak Koncer ke profesi lainnya menggeser nilai - nilai masyarakat yang ada. Pergeseran nilai dari agraris ke industri memberikan dampak postif dan negatif bagi masyarakat tersebut. Masyarakat industri cenderung konsumeristis, status sosial seseorang dalam masyarakat bukan lagi diukur dari kepemilikan sawah yang luas atau jumlah kerbau yang banyak, tetapi sudah berganti dengan berbagai barang elektronika atau mekanik, seperti: radio, televisi, motor, mobil, dan lain-lain. Glamournya para bintang layar kaca atau layar perak menjadi idola baru masyarakat, menggeser posisi primadona Menak Koncer di daerahnya sendiri. Mudahnya menikmati berbagai hiburan yang disajikan oleh media elektronika, menyebabkan mereka enggan untuk bersusah payah mengeluarkan biaya, waktu dan tenaga mencari hiburan di luar rumahnya. Terlebih lagi, hiburan yang disajikan selain memiliki variasi banyak, juga memiliki pesona yang banyak pula. Sehingga tidak jarang, kehadiran hiburan yang disajikan menimbulkan berbagai silang pendapat di antara warga masyarakat.

Selain itu, kurangnya minat masyarakat terutama remaja dan pemuda dalam mempelajari kesenian Menak Koncer ini menjadi alasan mati surinya kesenian tersebut. Mereka cenderung menyukai bahkan meniru kebudayan luar. Adanya fasilitas seperti radio, televisi, internet, majalah yang banyak menampilkan kebudayaan asing membuat para pemuda dan remaja tidak dapat membendung keingintahuan mereka untuk mencoba dan meniru. Akhirnya, kesenian lokal mereka anggap sebagai hal yang kuno dan ketinggalan zaman, sementara kebudayaan asing mereka nilai lebih maju dan modern. Kesadaran masyarakat Sumowono untuk menjaga budaya lokalnya sekarang ini masih terbilang minim. Mereka cenderung memilih budaya asing yang lebih praktis dan sesuai dengan perkembangan zaman meskipun beberapa diantara budaya asing tersebut yang tidak sesuai dengan kepribadian bangsa.

Para pelaku seni tradisional Menak Koncer tergolong kurang kreatif dan inovatif. Banyak anggapan yang menyatakan bahwa kesenian tradisional tidak menghibur jika dibandingkan dengan kesenian yang disiarkan melalui televisi, yang sebagian besar adalah kesenian modern. Jika kondisi tersebut tidak diimbangi dengan kreatifitas para pelaku kesenian dalam rangka melakukan adaptasi terhadap perkembangan zaman, maka pelan-pelan kesenian Menak Koncer tersebut akan kehilangan pengikut atau penonton. Eksistensinya sebagai media hiburan akan hilang, posisinya akan terancam punah. Mengingat Menak Koncer adalah salah satu kesenian tradisional produk budaya yang rentan terhadap gempuran budaya asing. Sehingga di era modern seperti sekarang, untuk tetap eksis, para pelaku seni Menak Koncer harus bisa lebih kreatif mengemas keseniannya.

Kurangnya pemahaman pelaku seni Menak Koncer terhadap pentingnya manajemen yang baik dalam pengelolaan administrasi juga menjadi penyebab mati surinya kelompok kesenian tersebut. Sebagaialternatif untuk memberikan solusi atas masalah ini adalah dengan memfungsikan manajemen kesenian tradisional secara lebih efektif. Dengan harapan, bahwa kesenian Menak Koncer harus dikelola secara profesional, dan manajemen ini dapat berfungsi untuk mengatur pentas seni tradisional tanpa harus kehilangan akar budayanya. 
Menak Koncer yang konon mempunyai nilai-nilai luhur dan sarat pesan moral, kondisinya harus terus dipertahankan. Oleh segelintir orang yang masih terbeban akan keberadaan kesenian ini, dibentuklah suatu organisasi bernama Karya Budaya. Pembentukan organisasi ini semata-mata untuk menghidupkan kembali kesenian tradisional yang mereka miliki serta melestarikan budaya yang tekah diwariskan oleh masyarakat sebelumnya.

Menurut Edi Sedyawati, agar kebudayaan dapat lestari, yaitu selalu dapat mempertahankan eksistensinya, maka diperlukan upaya-upaya untuk menjamin keberlanjutannya antara lain dengan perlindungan, pengembangan, dan pemanfaatan. Pemanfaatan di sini meliputi upaya-upaya untuk menggunakan hasilhasil budaya guna berbagai keperluan, seperti untuk menguatkan citra identitas daerah, untuk pendidikan kesadaran budaya, untuk dijadikan muatan industri budaya, dan untuk dijadikan sebagai daya tarik wisata. Dengan demikian, pemanfaatan hasil-hasil budaya melalui pembangunan pariwisata merupakan salah satu langkah untuk menjaga agar kebudayaan dan hasil-hasilnya dapat lestari (Sedyawati, 2006: 76).

Pelestarian Menak Koncer harus dilakukan terutama oleh masyarakat pemiliknya sendiri. Peran masyarakat tersebut terhadap kepedulian kebudayaannya harus total. Mereka harus peduli terhadap nasib kesenian Menak Koncer yang hampir punah. Kepedulian itu baiknya juga dibarengi dengan sebuah aksi guna melestarikan dan menjaga kekayaan budaya yang memang sudah sepatutnya dilakukan oleh segenap bangsa Indonesia. Masyarakat harusnya mencoba mengembangkan kesenian tradisional menjadi bagian dari kehidupan modern, berupaya memodifikasi bentuk-bentuk seni yang masih berpolakan masa lalu untuk dijadikan komoditi yang dapat dikonsumsi masyarakat modern. Karena kesenian
Menak Koncer yang dimiliki masyarakat Sumowono merupakan salah satu budaya lokal milik Indonesia yang mewakili identitas bangsa. Untuk itu, kesadaran melestarikan dan menjaga Kesenian Menak Koncer dari dampak pergeseran budaya tetap harus dilakukan. Pembelajaran tentang budaya harus ditanamkan sejak dini. Karena melalui pembelajaran budaya, masyarakat dapat mengetahui pentingnya budaya lokal dalam membangun budaya bangsa yang berkepribadian.

Selain itu, optimalisasi peran lembaga kebudayaan perlu ditingkatkan. Lembaga-lembaga kebudayaan baik berupa lembaga swadaya masyarakat (LSM), sanggar, atau paguyuban merupakan elemen lain yang dapat berperan serta dalam pelestarian kesenian tradisional Menak Koncer. Sejauh ini lembaga kebudayaan dipandang sebagai elemen masyarakat yang relatif memiliki perhatian dan kepedulian terhadap eksistensi dan kelangsungan kesenian tradisional. Optimalisasi peran lembaga kebudayaan memerlukan dukungan pemerintah. Pemerintah berkewajiban memberikan dorongan dan ekpresi yang cukup demi kelangsungan seni Menak Koncer. Partisipasi pemerintah dapat berupa penyuluhan, pembinaan dan pelatihan bagi kelompok kesenian tradisional yang bertujuan untuk memberikan arah dalam pengembangan Menak Koncer. Pemerintah juga perlu memberikan intensif atau apapun namanya kepada lembaga kebudayaan yang memiliki komitmen, konsisten, dan secara kontinyu melakukan kegiatan-kegiatan pelestarian Menak Koncer. Pemerintah Provinsi Jawa Tengah maupun Pemerintah Kabupaten Semarang bertanggung jawab akan hal ini. 
HUMANIKA Vol. 23 No. 2 (2016) ISSN 1412-9418

Seni Pertunjukan Tradisional Di Persimpangan Zaman: Studi Kasus Kesenian Menak Koncer

Sumowono Semarang

Laura Andri R.M., S.S.,M.A.

\section{SIMPULAN}

Dalam uraian pendahuluan dapat dipahami bahwa kesenian tradisional Menak Koncer yang berkembang di daerah Sumowono Kabupaten Semarang Jawa Tengah awalnya dilakukan dalam rangka meningkatkan rasa patriotisme dan nasionalime. Pada perkembangan berikutnya, terutama pada masyarakat modern, pementasan kesenian Menak Koncer bergeser fungsinya hanya sekedar sebagai hiburan semata. Eksistensi Menak Koncer sebagai seni dan budaya tradisional di Indonesia semakin lama semakin tergerus oleh ekspansi seni dan budaya global. Jika hal ini terus berlangsung, maka masyarakat, khususnya masyarakat Sumowono semakin tidak apresiatif terhadap kesenian daerahnya sendiri. Mereka pada gilirannya nanti akan menjadi terasing dari seni dan budaya tradisional warisan leluhurnya. Dampak terburuknya, masyarakat ini akan berangsur kehilangan jati diri. Oleh karena itu, berbagai upaya harus dilakukan untuk melestarikan seni dan budaya daerah di tengah-tengah perubahan zaman dan pengaruh budaya asing yang semakin gencar di Indonesia.

\section{DAFTAR PUSTAKA}

Bandem, I Made. 2001. "Potensi Budaya Bangsa dalam Koridor Produk Wisata Berbasis Alam dan Budaya di Negara-negara Asean". Makalah Dipresentasikan dalam Tourism, Culture, and Art Forum di Melia Purosani Hotel, Semarang, 7 Desember.

Brandon, James R. 1970. The Theatre in Southeast Asia. Cambridge, Massachusset: Harvard University Press.

Koentjaraningrat. 1994. Kebudayaan Jawa. Jakarta: Balai Pustaka.

Martini, Laura Andri. 2007. "Manajemen Seni Pertunjukan Tradisional di Semarang (Wayang Orang Ngesti Pandowo, Suko Raras dan
Sobokarti)”. Penelitian Dosen Muda Fakultas Ilmu Budaya Undip.

Permas, Achsan, dkk. 2003. Manajemen Organisasi Seni Pertunjukan. Jakarta: PPM.

Sadiyah, Siti. 2011. Wayang Orang Ngesti Pandowo Bagi Penonton. (Penelitian)

Sedyawati Edi. 2006. Budaya Indonesia: Kajian Arkeologi, Seni dan Sejarah. Jakarta: RajaGrafindo Persada.

Soedarsono (A). 1986. "Dampak Modernisasi Terhadap Seni Pertunjukkan Jawa di Pedesaan.” Proyek Penelitian dan Pengkajian KebudayaanNusantara (Javanologi), Yogyakarta. 